\title{
Low regeneration of lesions produced by coring in Orbicella faveolata
}

Rosa E Rodríguez-Martínez, Adán Guillermo Jordán-Garza, Eric Jordán-Dahlgren

The extraction of tissue-skeleton cores from coral colonies is a common procedure to study diverse aspects of their biology, water quality or to obtain environmental proxies. Coral species preferred for such studies in Caribbean reefs belong to the genera Orbicella. The long term effects of coring in the coral colony are seldom evaluated and in many Caribbean countries this practice is not regulated. We monitored 50 lesions produced on Orbicella faveolata colonies by the extraction of two centimeter-diameter cores to determine if they were able to heal after a four year period. At the end of the study $4 \%$ of the lesions underwent full regeneration, 52\% underwent partial regeneration, $14 \%$ suffered additional tissue loss, but remained surrounded by live tissue, and $30 \%$ merged with dead areas of the colonies. Given the low capacity of Orbicella faveolata to regenerate tissue-skeleton lesions, studies that use coring should be regulated and mitigation actions, such as using less destructive techniques and remediation measures after extraction, should be conducted to facilitate tissue regeneration. 


\section{Low regeneration of lesions produced by coring in Orbicella \\ 2 faveolata}

3 Rosa Elisa Rodríguez-Martínez ${ }^{1}$, Adán Guillermo Jordán-Garza ${ }^{1}$, Eric Jordán-Dahlgren ${ }^{1}$

$4 \quad 1$ Unidad Académica Puerto Morelos. Instituto de Ciencias del Mar y Limnología,

5 Universidad Nacional Autónoma de México. Puerto Morelos, Quintana Roo, México.

6

7 Corresponding author:

8 Rosa Elisa Rodríguez-Martínez

9 Ap. Postal 1152, Cancún, Quintana Roo, 77500, México

10

11 Email address: rosaer@cmarl.unam.mx

12 


\section{Abstract}

14 The extraction of tissue-skeleton cores from coral colonies is a common procedure to study diverse aspects of their biology, water quality or to obtain environmental proxies. Coral species preferred for such studies in Caribbean reefs belong to the genera Orbicella. The long term effects of coring in the coral colony are seldom evaluated and in many Caribbean countries this practice is not regulated. We monitored 50 lesions produced on Orbicella faveolata colonies by the extraction of two centimeter-diameter cores to determine if they were able to heal after a four year period. At the end of the study $4 \%$ of the lesions underwent full regeneration, $52 \%$ underwent partial regeneration, $14 \%$ suffered additional tissue loss, but remained surrounded by live tissue, and $30 \%$ merged with dead areas of the colonies. Given the low capacity of

Orbicella faveolata to regenerate tissue-skeleton lesions, studies that use coring should be regulated and mitigation actions, such as using less destructive techniques and remediation measures after extraction, should be conducted to facilitate tissue regeneration.

\section{Keywords}

Coral; Tissue-skeleton lesions; Tissue regeneration; Core sampling

\section{Introduction}

The extraction of tissue-skeleton cores (cores) from reef-building coral colonies is a common procedure to study different aspects of their biology, such as growth rate (Hudson, 1981), calcification (Carricart-Ganivet et al., 2012), or the effect of diseases (Closek et al., 2014), or to study skeletal environmental proxies such as climate change

37 (Linsley et al., 2004), paleo-nutrient proxies (Mason et al., 2011), water quality

38 (McCulloch et al. 2003), or diagenesis (Müller et al., 2001). One of the preferred coral 
39

40

41

42

43

44

45

species used for such studies in Caribbean reefs is Orbicella faveolata, due to its importance as a reef builder and because their colonies can attain relatively large sizes and thus record information from tens to hundreds of years (Lough, 2010). A literature search on Google Scholar (http://www.scholar.google.com), showed that for the period between 2005 and 2015 there were 80 published peer reviewed and grey literature articles with the name Montastraea faveolata or Orbicella faveolata in the title (not considering those focused on fossil colonies), and that $23 \%$ of the studies involved the extraction of cores. Cores were extracted either with a hammer and a steel-core or with a pneumatic drill, their diameters ranged from 1.5 to $10 \mathrm{~cm}$, and their depth varied from a few centimeters to over one meter, depending on the study goals. Only in $22 \%$ of these studies did the authors mention that the holes left by the cores were filled with an artificial substrate (i.e. concrete plugs or epoxy) to facilitate the regeneration and expansion of the coral tissue, and none of the studies report a follow-up to determine if the injuries healed.

The extraction of cores from corals can deleteriously affect the remaining colony, as the lesion can enlarge due to predation, competition with other sessile organisms (i.e. algae, sponges, or tunicates), or by the effect of boring organisms or pathogens (Kramarsky-Winter \& Loya, 2000). The potentially negative effect of this methodology is important considering that $\mathrm{O}$. faveolata is an endangered species (IUCN Red list category) as its populations have suffered severe declines in the last several decades due to the synergistic effects of temperature stress, diseases (Edmunds \& Elahi, 2007), deterioration of environmental quality (Harvell et al., 1999; Daszak et al., 2001), and competitive interactions with algae, cyanobacteria, bio-eroding sponges and other 
62 competitors (Titlyanov et al., 2005; Bruckner \& Bruckner, 2006). Recovery of these

63 populations is compromised as species of the Orbicella annularis (complex) are known

64 for having low larval recruitment rates, slow growth rates $(\sim 6.3-11.2 \mathrm{~mm}$ of vertical

65 growth per year; Hudson, 1981) and moderate regeneration capabilities (Meesters et

66 al., 1997; Cróquer et al., 2002).

67 In some countries (e.g. United States and Panama) coral coring is regulated and

68 researchers are required to plug the holes to minimize the damage and maximize tissue

69 and skeleton recovery. In others (e.g. Mexico, Colombia) plugging the holes after coring

70 corals is not regulated nor enforced. This lack of control allows that local and visiting

71 researchers skip remediation techniques, which might be discarded as time consuming

72 and unnecessary.

73 Here, we evaluate the fate of lesions produced by the extraction of tissue-skeleton

74 cores for research purposes in colonies of the coral O. faveolata in a shallow Mexican

75 Caribbean reef. We evaluated lesion size and depth immediately after coring and after a

76 four year period, in apparently healthy and in yellow-band disease colonies, to

77 determine to what extent $O$. faveolata colonies can regenerate from this type of injury.

\section{Materials and methods}

80 Between September 2010 and February 2011, 50 cores were extracted, by another

81 research group for a genomic study, from 16 Orbicella faveolata colonies, all larger than

$8250 \mathrm{~cm}$ in diameter, on Puerto Morelos reef, Mexico $\left(20^{\circ} 52^{\prime} \mathrm{N}, 86^{\circ} 52^{\prime} \mathrm{W}\right) ; 12$ colonies 
83 were located in the back-reef ( $5 \mathrm{~m}$ deep) and four colonies were located in the fore-reef

84 (7 $\mathrm{m}$ deep). The number of lesions produced within a single coral colony ranged from

85 two to seven and the distance between them ranged from $0.1 \mathrm{~cm}$ to $30.4 \mathrm{~cm}$ (mean =

$866.0 \mathrm{~cm}, \mathrm{SE}=5.7 \mathrm{~cm}$ ). A map was made indicating the position of each colony that was

87 sampled within the reef site. A photograph of each colony was taken to indicate the

88 position of the tissue and skeleton extracted by each core. The cores were obtained

89 using a two $\mathrm{cm}$ circular steel-core and a hammer. Occasionally, additional injury during

90 the coring process occurred, resulting in the loss of a larger portion of tissue and

91 skeleton. The lesion produced by each core was immediately photographed with a

92 digital camera and the depth of the hole produced was measured in situ with a Vernier

93 caliper. After extraction, the core holes were not filled. Lesions were photographed

94 again in May 2015. The software ImageJ was used to calculate the projected area of

95 each lesion, using a 5-cm scale bar included in each image.

96 For the analysis, the cores were assigned to one of three sets: (1) 32 cores taken from

9711 apparently healthy $(\mathrm{H})$ colonies, (2) eight cores, taken from the yellow tissue of six

98 colonies with yellow-band disease (YB), and (3) ten cores, taken from apparently

99 healthy tissue on the same diseased colonies (hereafter called healthy-disease or HD).

100 During coring, the healthy and the healthy-disease cores were always completely

101 surrounded by live tissue, while the cores on the tissue with yellow band were not, due

102 to disease-induced mortality adjacent to the yellow band. The percent change in the

103 area of each lesion was estimated with respect to the original core measurement using

104 the following formulas:

105

1) $\Delta \mathrm{LA}=\mathrm{LAt} t_{0}-\mathrm{LAt} t_{1}$ 
106
2) $\% \Delta \mathrm{LA}=\frac{\Delta \mathrm{LA} \times 100}{\mathrm{LAt} 0}$

107 with $\Delta \mathrm{LA}=$ the change in lesion area $\left(\mathrm{cm}^{2}\right) ; \mathrm{LAt}_{0}=$ lesion area $\left(\mathrm{cm}^{2}\right)$ at time $0 ; \mathrm{LAt}_{1}=$

108 lesion area $\left(\mathrm{cm}^{2}\right)$ at time 1 ; and $\% \Delta \mathrm{LA}=$ the change in lesion area expressed as a

109 percentage from the original lesion. The sign of $\% \Delta L A$ indicates if tissue was lost

$110(\% \Delta \mathrm{LA}<0)$ or if the lesion recovered $(\% \Delta \mathrm{LA}>0)$.

111 Regeneration is expressed in terms of a reduction in lesion size. The possible outcomes

112 of the lesions were: (a) full regeneration, (b) partial regeneration, (c) additional tissue

113 loss, but remained completely surrounded by live tissue (Type I lesions: Meesters et al.,

114 1997), (d) lesion enlarged and merged with a dead area of the colony (Type II lesions:

115 Meesters et al., 1997) (Fig. 1).

116 The initial lesion areas were summed when they merged with adjacent core-produced

117 lesions, with calculations treating each merged group as a single large lesion. When a

118 lesion grew and merged with an area of the colony that lacked tissue it was excluded

119 from the analysis because it was impossible to differentiate between the tissue loss

120 associated to the core lesion and independent partial mortality.

121 Fieldwork was conducted within the Puerto Morelos Reef National Park under Permits

122 DGOPA.10607.031009.3548 (in 2010), DGOPA.00322.200111.0099 (in 2011) and

123 PPF/DGOPA-116/14 (in 2015), issued by the National Commission on Aquaculture and

124 Fisheries (Comisión Nacional de Acuacultura y Pesca). 
2010-2011

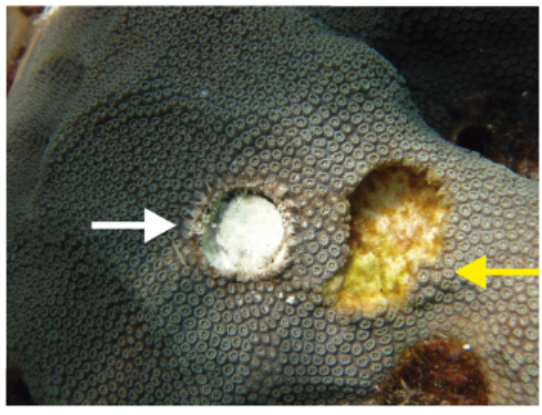

b

C
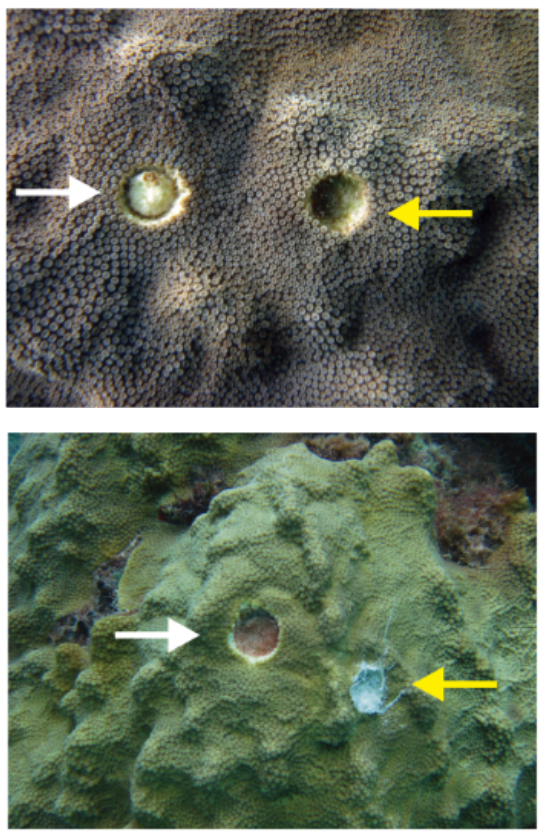

125

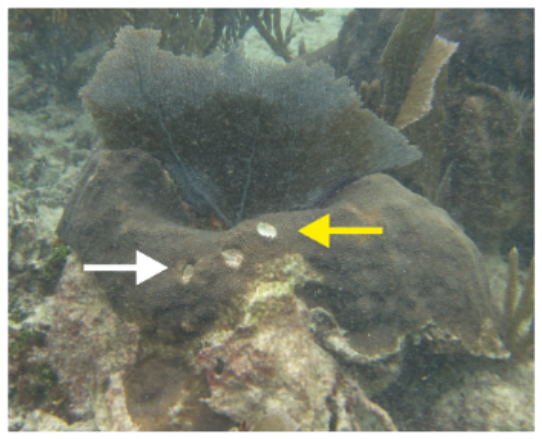

2015
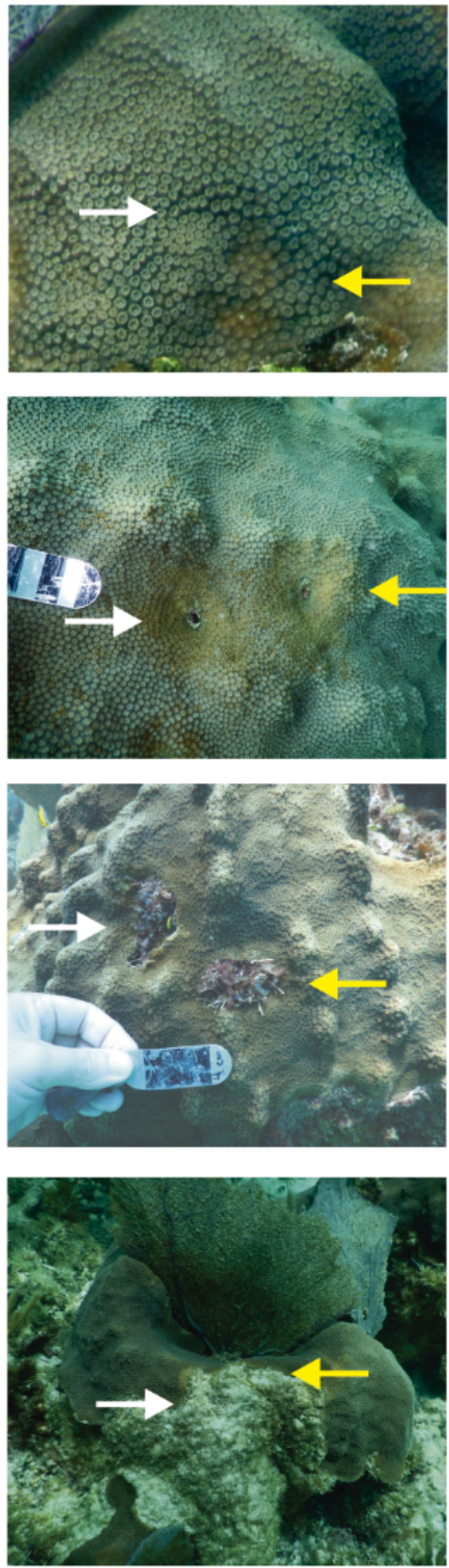

126 Figure 1. Examples of different outcomes of tissue-skeleton core lesions in Orbicella

127 faveolata: a) full regeneration, b) partial regeneration, c) additional tissue loss, but still

128 surrounded by live tissue and d) lesion merged with a dead area of the colony and is no

129 longer enclosed by live tissue. The photographs on the left were taken between

130 September 2010 and February 2011 and those on the right were taken in May 2015. 


\section{Results and Discussion}

132 At the beginning of the study, the mean core-lesion area was $4.0 \mathrm{~cm}^{2}(\mathrm{SD}=1.9)$, with a

133 mean depth of $1.4 \mathrm{~cm}(S D=0.8$, range: $0.42-2.19 \mathrm{~cm})$. After four years, two lesions

$134(4 \%)$ underwent full tissue regeneration, 26 lesions (52\%) underwent partial

135 regeneration, seven lesions (14\%) suffered additional tissue loss, but were still

136 surrounded by live tissue, and 15 lesions (30\%) merged with a dead area of the colony

137 and were no longer enclosed by living tissue.

138 After four years, none of the 32 lesions produced by the cores obtained from healthy-

139 looking colonies underwent full regeneration, partial regeneration occurred in $78 \%$ of the

140 cores which on average regenerated $61.9 \%(S D=25.3 \%)$ of the original area produced

141 by the lesion. The lesions produced by four cores increased in size (mean increment $=$

$142133.3 \%, S D=78.2 \%$ ) and in three cases the lesions merged with a dead area of the

143 colony and were no longer enclosed by living tissue in 2015 (Fig. 2). Of the ten lesions

144 on apparently healthy tissue of colonies with yellow-band disease, two underwent full

145 regeneration, another exhibited partial regeneration (regenerated area $=63 \%$ of the

146 lesion), three fused and together increased in size by $579 \%$, and four were no longer

147 enclosed by living tissue in 2015 (Fig. 2). All the cores obtained from yellow-band

148 diseased areas were no longer enclosed by tissue in 2015 (Fig. 2) due to the slow but

149 persistent progress of this disease (Bruckner \& Bruckner, 2006). The fact that the only

150 two lesions that underwent full regeneration were those produced in the healthy tissue

151 of one O. faveolata colony affected by yellow-band disease (Fig. 3) could be the result

152 of chance, yet, it is known that corals allocate their resources into three main

153 hierarchical processes, growth, maintenance and reproduction (Harrison and Wallace 
154 1990) and when stressful situations occur (e.g. disease) tissue regeneration is

155 frequently favored (Henry and Hart 2005).

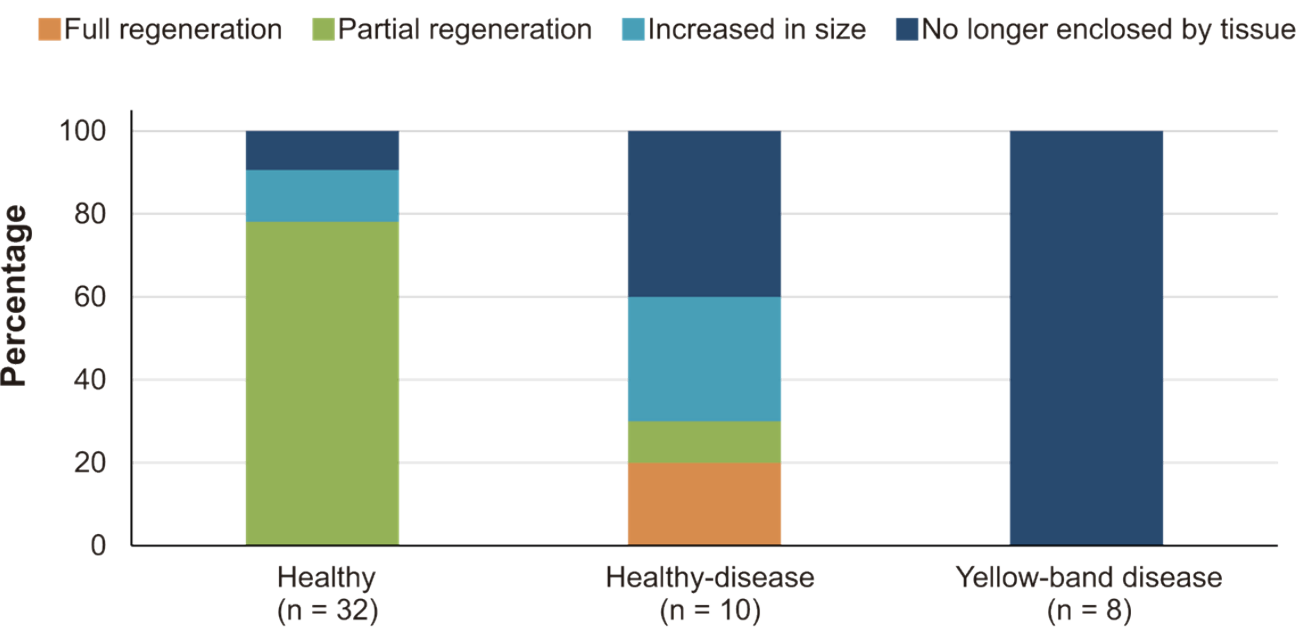

156

Outcome of the lesion

157 Figure 2. Percentage of lesions that underwent full and partial regeneration of tissue 158 and those that increased in size or were no longer enclosed by live tissue in healthy, 159 healthy-disease, and yellow-band disease colonies between 2010-2011 and 2015.

161 In all cases, the area of the coral colony that was cored appeared indented on the

162 colony surface (Fig. 1b) suggesting that coral growth around the lesion was suppressed

163 or hampered, as previously reported in O. annularis by Meesters et al. (1994). The

164 formation of septa, polyps, and internal skeletal structures likely results in reduced linear

165 growth because the coral allocates resources to skeletal and tissue regeneration (Henry

166 \& Hart, 2005).

167 The identity of the coral colony had no apparent effect on the outcome of the

168 regeneration of lesions, as lesions within the same colony showed a variable degree of

169 regeneration (Fig. 3). Although regenerative capacity has a genetic basis (Meesters et 
170 al., 1996), our observations suggest that, within the same colony, extrinsic factors (e.g.

171 micro-habitat, somatic mutations, different strains of zooxanthellae) can modulate the

172 rate and success of lesion recovery.

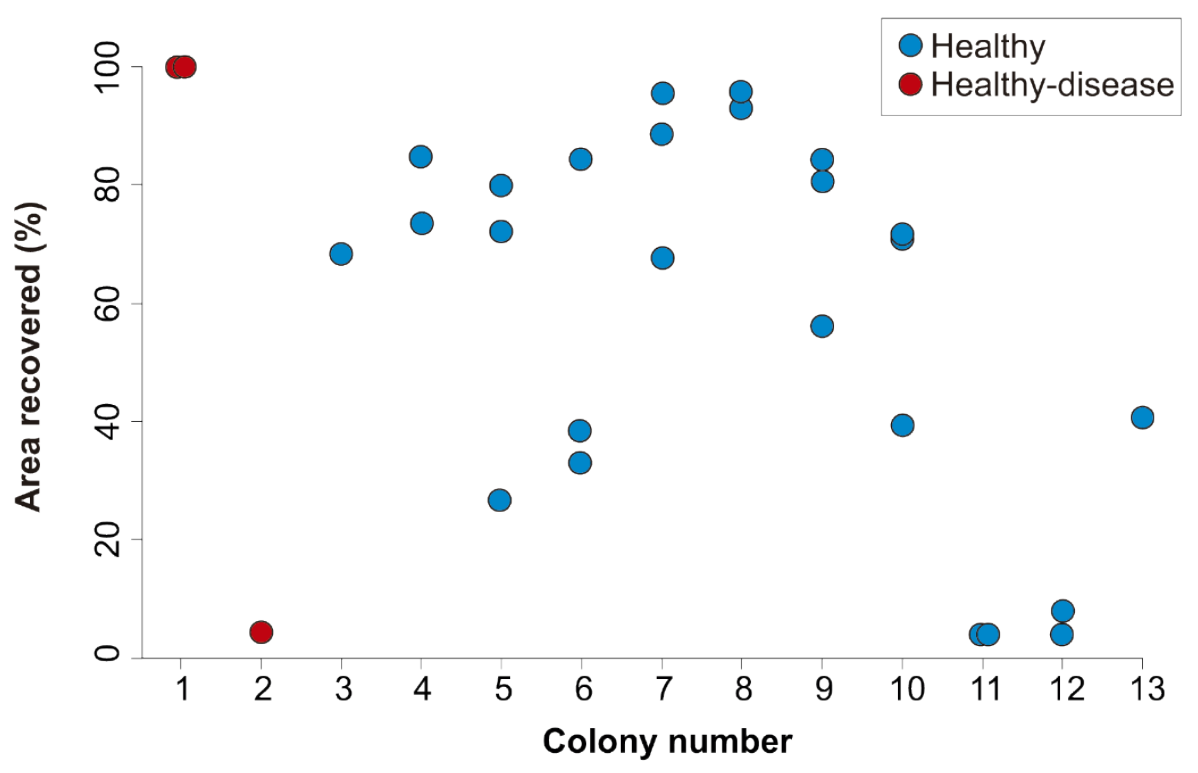

174 Figure 3. Percent area recovered four years after the extraction of tissue-skeleton

175 cores from 13 colonies of Orbicella faveolata. The number of lesions varied from one to 176 three per coral colony. Only the colonies where lesion regeneration occurred are shown 177 in the figure.

178

179 The distances between lesions within a single colony didn't have an effect on the fusion

180 of lesions; of the 64 cases in which colony fusion could occur, this happened in only

181 nine cases and subsequent tissue loss occurred only in one case.

182 In $84.6 \%$ of the lesions that underwent partial regeneration, the coloration of the polyps

183 surrounding the lesions was pale, suggesting a lower number of zooxanthellae or

184 chlorophyll than in the rest of the colony (Fig. 1b). After observing a similar condition in

185 O. annularis colonies weeks after the complete regeneration of artificially produced 
186 lesions, Bak et al. (1977) suggested that this was due to the expulsion of zooxanthellae.

187 We propose that the pale coloration might also be associated with the presence of

188 algae on unhealed lesions, especially when mixed turf algae (MTA) that trap sediments

189 are present, as these have been reported to cause reductions in zooxanthellae

190 densities and chlorophyll a concentrations in O. faveolata (Quan-Young \& Espinoza-

191 Avalos, 2006). In our study, MTA occupied unhealed lesions in $58 \%$ of the cases,

192 calcareous coralline algae in $31 \%$ of the cases and fleshy algae in $11 \%$ of the cases.

193 The tissue around the lesions was pale in $73.3 \%$ of unhealed lesions covered by MTA

194 and in all lesions covered by calcareous coralline algae and fleshy algae. Further

195 studies are needed to determine if the observed paling around lesions is indeed caused

196 by the presence of MTA and other types of algae. Some benthic algae can also

197 outcompete corals, increase coral stress, and are believed to act as reservoirs for a

198 variety of different potential coral pathogens (Sweet et al., 2013) and contribute to

199 additional tissue loss.

200 Given the low capacity of $O$. faveolata to regenerate lesions that involve the removal of

201 tissue and skeleton (Cróquer et al., 2002, Sánchez et al., 2004), we conclude that

202 scientific studies that require the extraction of cores should design sampling protocols

203 that minimize damage to colonies. Plugging core-holes with cement, epoxy or recycled

204 skeletom from dead colonies in order to provide a hard substrate over which new coral

205 tissue can spread may also prevent recruitment of boring organisms that can weaken

206 the coral skeleton. This approach has allowed complete regeneration of tissue in some

207 scleractinian coral species, such as Pseudodiploria strigosa, P. clivosa, and Diploria

208 labyrinthiformis (Weil and Vargas, 2010), but not in others, such as Meandrina 
209 meandrites and Montastraea cavernosa (Fahy et al., 2006). In a study conducted by

210 Fisher et al. (2007), the filling of artificial lesions in Orbicella spp. with clay didn't prove

211 to be effective, as only $13.1 \%$ of 229 lesions (area: $0.8-3.0 \mathrm{~cm}^{2}$, depth: $3 \mathrm{~mm}$ ) healed.

212 These controversial results indicate that more studies are needed to find the best way to

213 reduce long-term damage due to coring coral colonies. In the meantime, all countries

214 with coral reef ecosystems should regulate this research technique and permits to

215 employ it should establish mitigation actions to avoid damaging key coral species. Even

216 if regulations are not established in a particular country researchers should use

217 mitigation techniques whenever samples are obtained from this important and

218 endangered species.

220 Conclusions

221 Orbicella faveolata has low capacity to fully regenerate tissue-skeleton lesions produced

222 by coring. Scientific studies that employ this sampling technique should minimize its

223 effects by reducing the diameter and depth of cores and by plugging the holes.

224 Environmental authorities from countries with coral reef ecosystems should regulate this

225 sampling technique to reduce the impact from scientific studies on key reef-building

226 species.

\section{Acknowledgments}

228 This manuscript was greatly improved by comments from Carly Randall, Paul Blanchon,

229 Bronwyn Rotgans and an anonymous reviewer. 


\section{References}

232 Bak RPM, Brouns JJWM, Heys FML. 1977. Regeneration and aspects of spatial competition in the

233 scleractinian corals Agaricia agaricites and Montastraea annularis. Proceedings $3^{\text {rd }}$ International Coral

234 Reef Symposium: 143-148

235 Bruckner AW, Bruckner RJ. 2006. The recent decline of Montastraea annularis (complex) coral

236 populations in western Curaçao: a cause for concern. Revista de Biología Tropical 54: 45-58

237 Carricart-Ganivet JP, Cabanillas-Teran N, Cruz-Ortega I, Blanchon P. 2012. Sensitivity of calcification to

238 thermal stress varies among genera of massive reef-building corals. PLoS One, 7(3), e32859.

239 doi:10.1371/journal.pone.0032859

240 Closek CJ, Sunagawa S, DeSalvo MK, Piceno YM, DeSantis TZ, Brodie EL,Weber MX, Voolstra CR,

241 Andersen GL, Medina M. 2014. Coral transcriptome and bacterial community profiles reveal distinct

242 Yellow Band Disease states in Orbicella faveolata. The ISME journal 8: 2411-2422

243 Cróquer A, Villamizar E, Noriega N. 2002. Environmental factors affecting regeneration of the reef-

244 building coral Montastraea annularis (Faviidae) at Los Roques National Park, Venezuela. Revista de

245 Biología Tropical 50: 1055-1065

246 Daszak P, Cunningham AA, Hyatt AD. 2001. Anthropogenic environmental change and the emergence of 247 infectious diseases in wildlife. Acta Tropica 78:103-116

248 Edmunds PJ, Elahi R. 2007. The demographics of a 15-year decline in cover in the Caribbean reef coral

249 Montastraea annularis. Ecological Monographs 77: 3-18

250 Fahy EG, Dodge RE, Fahy DP, Quinn TP, Gilliam DS, Spieler RE. 2006. Growth and survivorship of 251 scleractinian coral transplants and the effectiveness of plugging core holes in transplant donor colonies.

252 Proceedings $10^{\text {th }}$ International Coral Reef Symposium: 1657-1664

253 Fisher EM, Fauth JE, Hallock P, Woodley CM. 2007. Lesion regeneration rates in reef-building corals

254 Montastraea spp. as indicators of colony condition. Marine Ecology Progress Series 339: 61-71

255 Harrison P, Wallace CC. 1990. Reproduction, dispersal and recruitment of Scleractinian corals. In:

256 Dubinsky Z (ed). Ecosystems of the world. Vol 25. Coral reefs. Elsevier, NY. 133-207

257 Harvell CD, Kim K, Burkholder JM, Colwell RR and 9 others. 1999. Emerging marine diseases—climate

258 links and anthropogenic factors. Science 285:1505-1510

259 Henry LA, Hart M. 2005. Regeneration from injury and resource allocation in sponges and corals - a

260 review. International Review of Hydrobiology 90(2): 125-158 
261 Hudson JH. 1981. Growth rates in Montastraea annularis: a record of environmental change in Key Largo 262 Coral Reef Marine Sanctuary, Florida. Bull Mar Sci 31: 444-459

263 Kramarsky-Winter E, Loya Y (2000) Tissue regeneration in the coral Fungia granulosa: the effect of

264 extrinsic and intrinsic factors. Marine Biology 137: 867-873

265 Linsley BK, Wellington GM, Schrag DP, Ren L, Salinger MJ, Tudhope AW. 2004. Geochemical evidence 266 from corals for changes in the amplitude and spatial pattern of South Pacific interdecadal climate

267 variability over the last 300 years. Climate Dynamics 22: 1-11

268 Lough JM. 2010. Climate records from corals. Wiley Interdisciplinary Reviews: Climate Change 1: 318-

269 331Mason HE, Montagna P, Kubista L, Taviani M, McCulloch M, Phillips BL. 2011. Phosphate defects

270 and apatite inclusions in coral skeletal aragonite revealed by solid-state NMR spectroscopy. Geochimica

271 et Cosmochimica Acta 75: 7446-7457

272 McCulloch M, Fallon S, Wyndham T, Hendy E, Lough J, Barnes D. 2003. Coral record of increased

273 sediment flux to the inner Great Barrier Reef since European settlement. Nature 421: 727-730

274 Meesters EH, Noordeloos M, Bak RPM. 1994. Damage and regeneration: links to growth in the reef

275 building coral Montastraea annularis. Marine Ecology Progress Series 112: 119-128

276 Meesters EH, Wesseling I, Bak RPM. 1996. Partial mortality in three species of reef-building corals and

277 the relation with colony morphology. Bulletin of Marine Science 58(3): 838-852.

278 Meesters EH, Pauchli W, Bak RPM. 1997. Predicting regeneration of physical damage on a reef-building 279 coral by regeneration capacity and lesion shape. Marine Ecology Progress Series 146: 91-99

280 Müller A, Gagan MK, McCulloch MT. 2001. Early marine diagenesis in corals and geochemical

281 consequences for paleoceanographic reconstructions. Geophysical Research Letters 28: 4471-4474

282 Quan-Young, L.I., Espinoza-Avalos J. 2006. Reduction of zooxanthellae density, chlorophyll a

283 concentration, and tissue thickness of the coral Montastraea faveolata (Scleractinia) when competing with

284 mixed turf algae. Limnology and Oceanography 51: 1159-1166

285 Sánchez J, Gil M, Chasqui LH, Alvarado EM. 2004. Grazing dynamics on a Caribbean reef-building coral. 286 Coral Reefs 23: 578-583

287 Sweet MJ, Bythell JC, Nugues MM. 2013. Algae as reservoirs for coral pathogens. PLoS ONE 8(7):

288 e69717. doi:10.1371/journal.pone.0069717

289 Titlyanov EA, Titlyanova TV, Yakoleva IM, Nakano Y, Bhagooli R. 2005. Regeneration of artificial injuries 290 on scleractinian corals and coral/algal competition for newly formed substrate. JEMBE 323: 27-42

291 Weil E, Vargas WL. 2010. Comparative aspects of sexual reproduction in the Caribbean coral genus

292 Diploria (Scleractinia: Faviidae). Marine Biology 157: 413-426 